\title{
Study of the Conditions of Formation and Forecast of the Perspective Areas of Hydrogen-Sulfide Water of Surkhandarya Depression
}

\author{
Rakhimjan Abdurazakovich Umurzakov, Muzaffar Rakhmatovich Zhuraev, \\ Rustam Yunusovich Yusupov
}

Tashkent State Technical University, Tashkent, Uzbekistan

Email: umrah@mail.ru,juraevm@inbox.ru,yusupov@tdtu.uz

How to cite this paper: Umurzakov, R.A., Zhuraev, M.R. and Yusupov, R.Y. (2019) Study of the Conditions of Formation and Forecast of the Perspective Areas of Hydrogen-Sulfide Water of Surkhandarya Depression. Open Journal of Geology, 9, 213-225. https://doi.org/10.4236/ojg.2019.94015

Received: March 15, 2019

Accepted: April 23, 2019

Published: April 26, 2019

Copyright $(\odot 2019$ by author(s) and Scientific Research Publishing Inc. This work is licensed under the Creative Commons Attribution International License (CC BY 4.0).

http://creativecommons.org/licenses/by/4.0/

\begin{abstract}
Increase in requirement of hydrosulphuric water for improvement of the population set the task of identification of places of their possible congestion for hydrogeological service. Earlier detection of such congestions was accidental at well-drilling of different function. Therefore, development of new methodical approaches of search and allocation of perspective zones of their formation was required. It was for this purpose necessary to study in what conditions and what factors have an impact on formation of underground hydrosulphuric water. So far, definition of communication attempts only with separate geochemical signs was known. Results of studying of influence on formations of hydrosulphuric water of such factors as lithologic and facial in combination with oil-and-gas content, the geological and structural and hydrodynamic mode are given in this work. It is established that the main sign for formation of hydrosulphuric water is existence of evaporite thickness and hydrocarbon congestions. Besides, it is shown that small depth (up to $2 \mathrm{~km}$ ) of their bedding has to be an indispensable condition and existence of explosive violation on which there has to be a water infiltration (a geological and structural factor). In the Surkhandarya region, the hydrodynamic mode caused by inclined bedding of aquifers was also one of essential factors. Active water is an exchange process with washing away (oxidation) sulfate of the containing thicknesses and subsequently, its restoration in interaction with hydrocarbons with formation of hydrosulphuric water is described. The technique is developed and the expected card of perspective zones of formation of hydrosulphuric water is constructed.
\end{abstract}

\section{Keywords}

Hydrosulfuric Water, Oil and Gas Complexes, Formation Conditions, Factor, 
Lithologic Facies, Geostructural, Hydrodynamics of Ground Water, Expected Map

\section{Introduction}

In the last decade, demand of society for hydrosulphuric water which is used for improvement of the population increased. It is connected with the fact that in scientific literature, influence of hydrogen sulfide $\left(\mathrm{H}_{2} \mathrm{~S}\right)$ on human health is widely discussed [1] [2] [3]. It was established that hydrogen sulfide $\left(\mathrm{H}_{2} \mathrm{~S}\right)$ prolongs life expectancy of nematode Caenorhabditis elegans [2] and has an impact on current of a number of diseases and life expectancy of the person [3].

Therefore, hydrosulphuric (sulphidic) mineral waters have medicinal properties and are used in sanatorium clinics at improvement of the population. Resort and sanatorium clinics actively work in many European countries on the basis of the known sulfide (hydrosulphuric) mineral waters: Pyeshtyana (Slovakia), Agia Paraskevi (Greece), Afyon and Marmaris (Turkey), Harkan, Eger (Hungary), resort of Lyondek Zdruy, Busko-Zdruy (Poland), etc.

Now in Uzbekistan, the only large sanatorium Chimion is based on hydrosulphuric water of the Fergana Valley functions. There is information on availability of hydrosulphuric water not only in the Fergana, but also in Surkhandarya and Amu Darya basins. However, the degree of their study is different and also demands detailed researches.

Studying of conditions of formation of underground hydrosulphuric water and development of expected perspective cards of zones of congestion between them within certain territories will allow to plan and carry out medical and improving and tourist activity.

The research area is located within the southern Uzbekistan (Figure 1), including the Surkhandarya Basin. It forms the Western part of the South Tajik Depression. In the North-West, the Depression is located in the junction with the South-Western spurs of Hissar. In the North, it is adjacent to the foothills of the Hissar Range. Within the territory of Central Asia, features of formation of hydrosulphuric water were studied separately: both across certain territories, and on indicators of factors. Separate works in which hydrogeochemical data were discussed and discussed [4] [5] are known. The publications devoted to study the conditions of formation of hydrosulphuric water practically do not meet, or very few. There are works in which the possibility of extraction of hydrogen sulfide when developing oil and gas fields is shown [6]. It is noted that water rich with sulfides can rise from depths and can influence its distribution in the top layers [7]. The analysis of concentration of hydrogen sulfide in the environment in connection with development of mineral deposits is described in [8].

The problem of formation of hydrosulphuric water in new aspect is considered in Articles [9] [10] [11]. These articles are devoted to the description of 

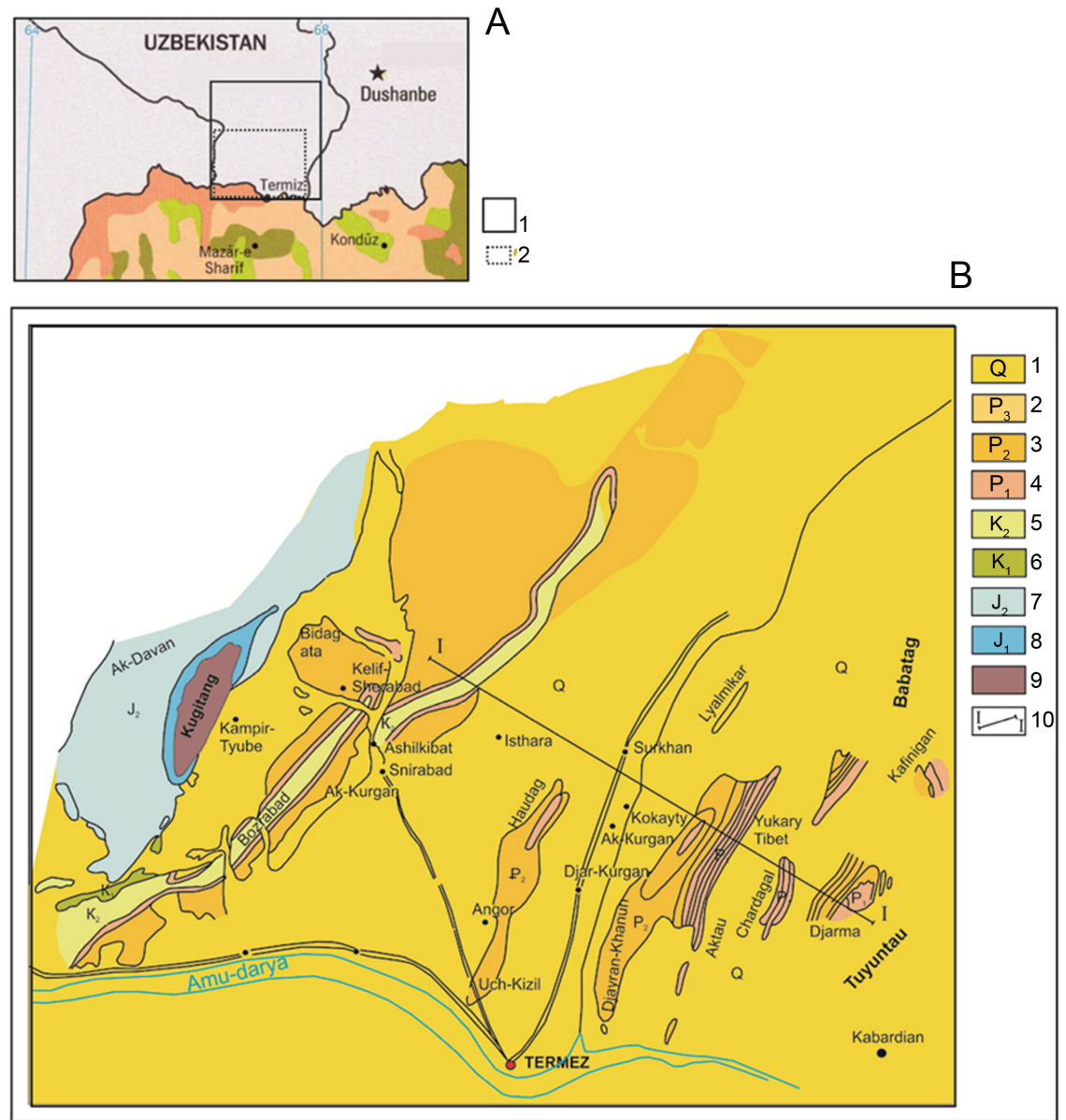

Figure 1. The position of the study area (A) and a fragment of the geological map (B). Symbols: (A) 1-the investigated area; 2-the area of the fragment of the geological map. (B) 1-Quaternary system; 2 - 4-Paleogene system: departments: 2-upper, 3-middle, 4-lower; 5 - 6-chalk system: 5-upper, 6-lower; 7 - 8-Jurassic system: departments: 7-upper, 8-lower; 9-Paleozoic system; 10-geological profile line.

separate results of studying of influence on formation of underground hydrosulphuric water of lithofacial and geological and structural factors.

For the most complete study of the features of the formation of hydrogen sulfide water in order to find and predict the likely places of accumulation, it is necessary to take into account the complex, if it is possible, of all Factors. These include: lithofacial, geological-structural, hydrodynamic, geothermal. To date, there have been no studies on the influence of these Factors on the formation of hydrogen sulfide water on the territory of Uzbekistan. Geothermal factor is not yet considered, this will be devoted to a separate work.

It is known that the concentration of hydrogen sulfide hydrogen sulfide Water is conditionally is divided into water of low concentration $(10-50 \mathrm{mg} / \mathrm{l})$, medium $(50-100 \mathrm{mg} / \mathrm{l})$ and strong $(100-250 \mathrm{mg} / \mathrm{l})$ [7] [12]. Among them, the conditions of formation differ nitrogen, hydrogen sulfide, methane water. In this paper we consider only the conditions of formation of hydrogen sulfide water. We have an opinion that the sulphurous water is formed in peat bogs in the re- 
covery process of sulphate. However, there are no such peatlands within Central Asia. And therefore here it is necessary to study more deep, underground conditions of formation of hydrosulphuric water.

\section{Materials and Methods}

Areas of distribution of hydrogen sulfide are usually confined to the oil and gas Basins of platform and folded areas, in the context of which evaporite deposits are developed. The largest amount of hydrogen sulfide is observed in the Water of open (exposed at the surface) and oil fields disturbed by the fault - where there is a connection with surface water [4] [5] [6]. For the Surkhandarya hollow the ratio oil-and-gas and the evaporite of thicknesses in cuts of certain squares is shown in Figure 2 and Figure 3. Within the studied region at Haudag Square in well 5 in the paleogenovykh deposits of the oil-bearing field strong brine waters, chloride - sodium-calcium, strong hydrosulphuric and marginal are revealed.

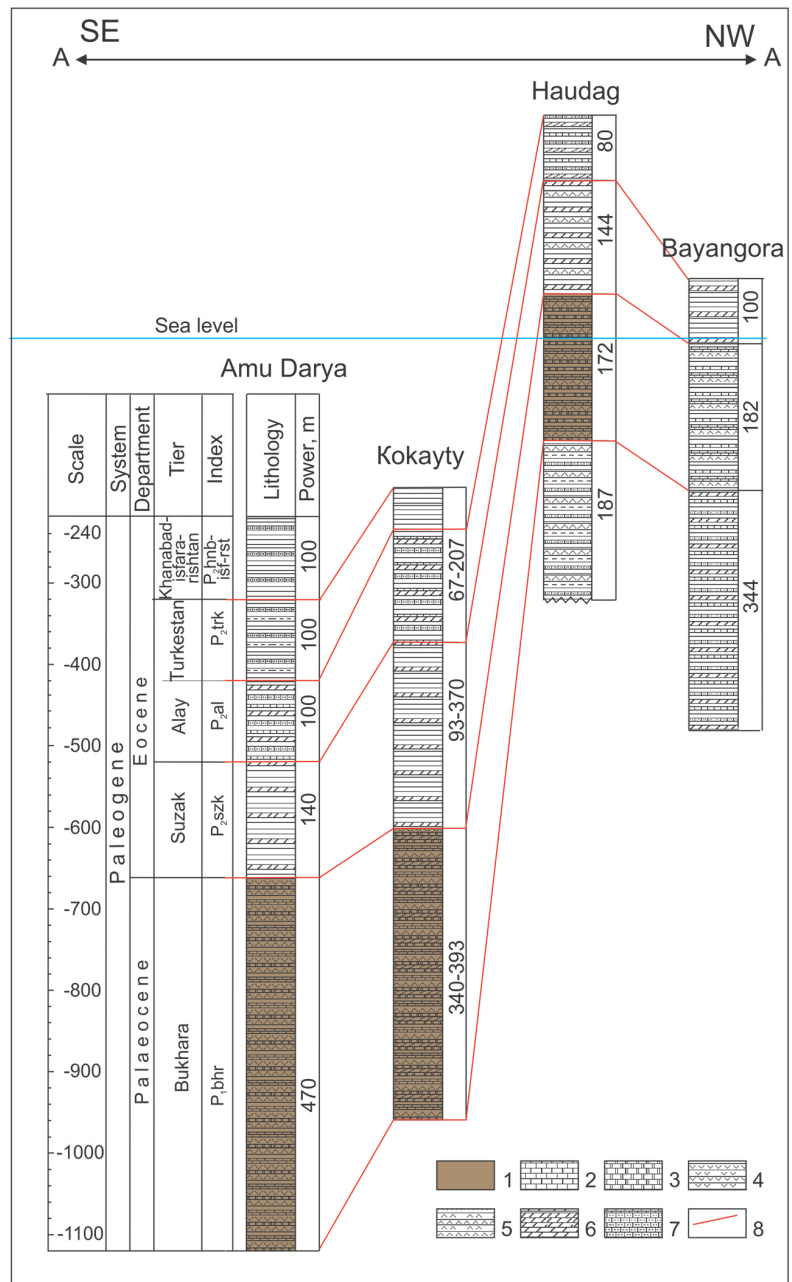

Figure 2. Map of comparison of Paleogene deposits of the Surkhandarya depression along profile A-A (the positions of the profiles are shown in the figure) (Legend: 1-oil-bearing complexes; 2-limestone; 3-dolomite; 4-gypsum; 5-Angdrites; 6-marl; 7-sandstone; 8-correlation lines). 


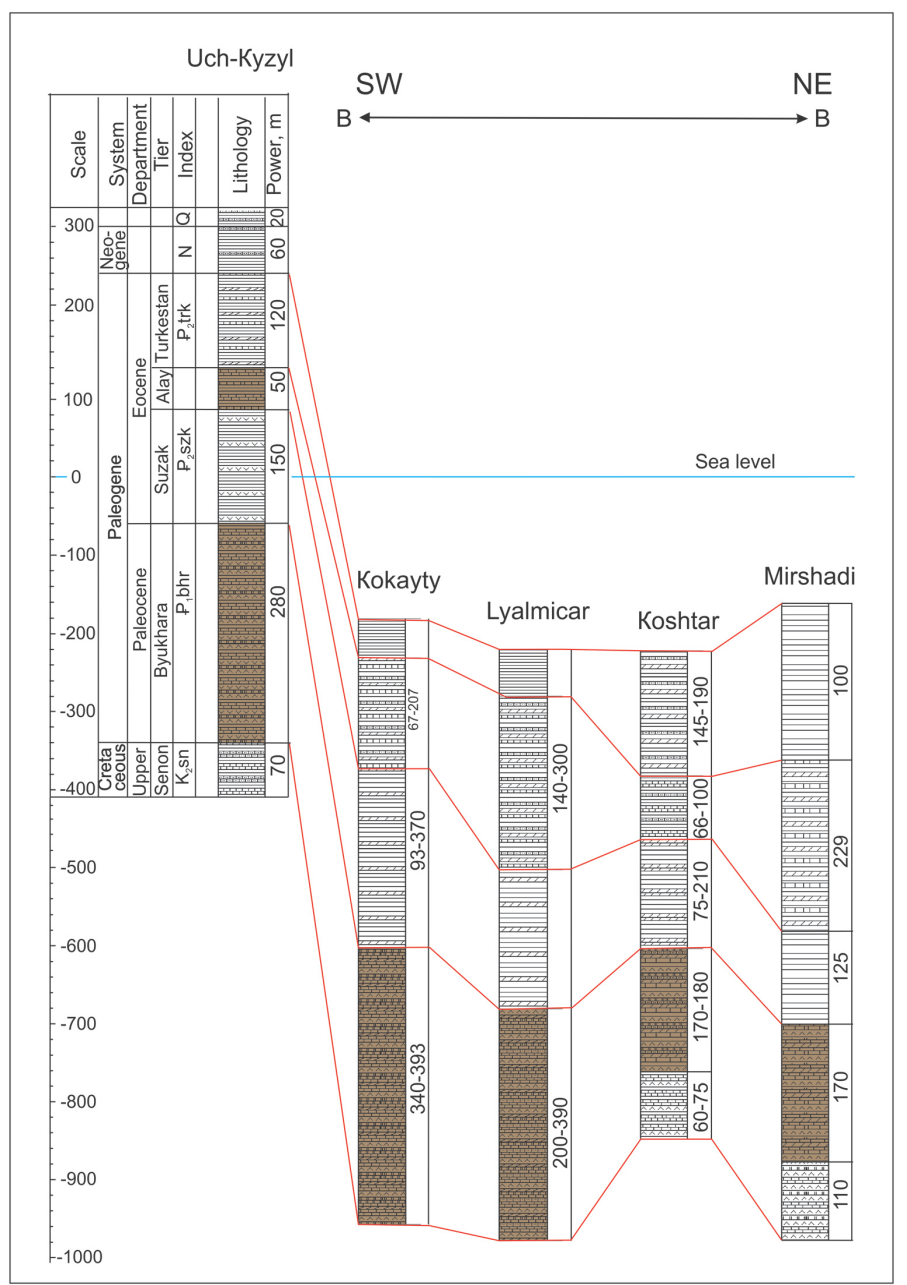

Figure 3. Scheme for comparing Paleogene sediments of the Surkhandarya depression along profile $\mathrm{BB}$ (the positions of the profiles are shown in the figure) (For conventions, see Figure 2).

In hard currency 2 are received strong brine, chloride - sodium-calcium, strong hydrosulphuric water with a high output. In the oil-bearing field of Kokayta are revealed brine, chloride - sulfate-sodium calcium, strong hydrosulphuric water with a small output. In a pribortovy part of the Surkhandarya hollow (at Tuyuntau Square) deposits of chalk, Yura and the Paleozoic lie closer to the Earth's surface. In this part Paleogen deposits come to a surface. In the direction to the center of the hollow of adjournment MZ-KZ of a complex gradually fall. Power of deposits of the Neogene increases to $3000 \mathrm{~m}$. The roof of Paleozoic educations lies at a depth about $-7000 \mathrm{~m}$ (Ashurkhan Square). In the direction from the center of the hollow to the adjournment MZ-KZ West again gradually rises. In the western peripheral part of the hollow it comes to a surface again. The tectonic breaks crossing anticlinal structures lie at an angle about $45^{\circ}$.

Formation of hydrogen sulfide in ground Water, their concentration and dispersion are determined by hydrodynamic and closely related hydrogeochemical conditions [8]. The ratio and stability of the various sulfur compounds in ground- 
water are determined by the combined effects of Ur and $\mathrm{hH}$. Sulfur migrates in the Water environment in the form of sulphate sulphur. In acidic reducing medium stable sulfur-containing component $\mathrm{H}_{2} \mathrm{~S}$ at different $\mathrm{pH}$ values on $\mathrm{HS}$ (at $\mathrm{pH}=7)$ and $\mathrm{S} 2(\mathrm{pH}=14)[5][10][11]$.

As a rule, its distribution depends on the development of sulfate-reducing bacteria in them, but in some hydrogeological closed structures with a high content of hydrogen sulfide are not found. This gave a rise to microbiologists to argue that the process of sulfate reduction is carried out only in the presence of water exchange. Sulfates of various minerals (gypsum, barite, celestine, etc.) and organic compounds are used in the vital activity of sulfate-reducing bacteria [4] [5]. Formation of hydrogen sulfide water occurs according to the following chemical reaction:

$$
\mathrm{SO}_{4}^{2-}+2 \mathrm{C}_{\text {org }}+2 \mathrm{H}_{2} \mathrm{O}=\mathrm{H}_{2} \mathrm{~S}+2 \mathrm{HCO}^{3-}
$$

For allocation of perspective areas of accumulation of hydrogen sulfide Water it is necessary, first of all, to define zones favorable for its formation in geological section of the studied Basin. The papers [4] [7] [8] discussed some aspects of this problem, including the main search features of the places of formation of hydrogen sulfide water. However, they have the general character and are not presented to a uniform technique. Our researches have a specific goal of studying of signs and their use for allocation of expected sites of a congestion of hydrosulphuric water.

The analysis of the materials of previous years showed that in General, the prospecting work and the method of allocation of promising areas for the formation of hydrogen sulfide can be reduced to the phased implementation of the following tasks: 1) the relationship of the spread of hydrogen sulfide Water with sulphate-containing and oil and gas-bearing sedimentary complexes is studied; 2) the influence of the structural-tectonic factor on the formation and placement of hydrogen sulfide water accumulations is studied; 3) the hydrodynamic regime of the territory and its influence on the formation of hydrogen sulfide water.

Lithofacial analysis is one of the main parts of the method of allocation of places and conditions of formation of hydrogen sulfide water. This analysis was performed on the basis of the use of materials of geological sections on wells of certain areas of the studied region. It was attracted by the published material on the distribution of hydrocarbons (HC) within the study region. In sections allocated areas of distribution of evaporite formations and the presence of hydrocarbon deposits. It will be shown below that such areas were the most favorable for the formation of hydrogen sulfide water. Studies have shown that another equally important factor affecting the distribution of zones of formation of hydrogen sulfide water is the hydrodynamic regime of the studied Basin.

It is caused by features of a geological section of the studied territory (Figure 4) and distribution of an underground water stream. Here the areas of various level of a hydropressure of underground waters and distribution in them hydrosulphuric water is allocated. From a geological section it is visible that sheathe 


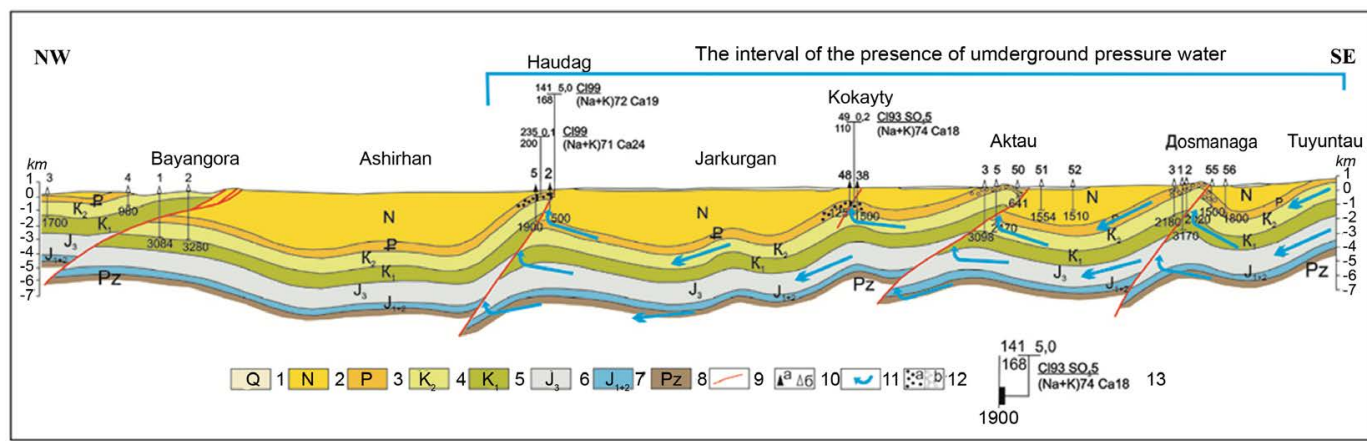

Figure 4. Hydrogeological profile of the Tuyuntau-Bayangor site with a reflection of the underground hydrodynamics and the conditions for the formation of hydrogen sulfide water. Legend: Geological complexes of sedimentary formations with age: 1-Quaternary, 2-Neogene, 3-Paleogene. Cretaceous system, department: 4-top, 5-bottom. Jurassic system, department: 6-upper, 7-lower and middle sections undifferentiated; 8-Paleozoic system; 9-tectonic disturbances; 10-oil wells: a-production, $\mathrm{b}$-exploration; 11-the direction of the flow of formation water; 12-distribution of hydrogen sulfide water (a), approximate (b); 13-well, at the top-the number, at the bottom-the depth, m. Zones of the main water inflows. Left: in the numerator-mineralization, g/l; the denominator is the concentration of hydrogen sulfide, $\mathrm{mg} / \mathrm{l}$. Right: in the numerator-the flow rate, $1 / \mathrm{s}$ and the chemical composition of water.

area of food is east peripheral part of the hollow. Paleogen deposits are bared within squares of Aktau and Domanaga. Here the oil-bearing fields are found. Paleogen deposits receive feed from a surface water here. The reservoir water of the MZ-KZ complex flowing from the East rest is against waterproof thicknesses-the structures formed as a result of tectonic violations. Here reservoir water pass into pressure head-there is an unloading of underground water.

Water exchange promotes oxidizing process due to washing away sulfate of the containing thickness (gypsiferous breed) of the Paleogene and recovery reaction in interaction with organic chemistry of oil-bearing thickness. As a result of this process hydrosulphuric water is formed. Existence of fields of $\mathrm{HC}$ and the evaporit of thicknesses (Figure 2 and Figure 3 ) in a geological structure of the region creates necessary conditions for this purpose. In cuts of various areas sites with such conditions on the A-and lines (Figure 2) and B-B (Figure 3) were allocated. Here the Bukhara and akzharsky layers the paleogenovykh of deposits Amu Darya, Kokayti and Haudag the areas are oil-and-gas. From Figure 2, it can be seen that hydrocarbon deposits are not detected on the Bayangor area. The total thickness of the Bukhara-Akzhar layers in the Amu Darya Square is $470 \mathrm{~m}$, in the Kokayty Square-393 m, and at the Haudag Square-172 m. On the Bayangor Square, their capacity is $182 \mathrm{~m}$. In the section, there is an alternation of the main water-bearing rocks of the Bukhara-Akzhar layers, represented by limestones and dolomites. Among them are koown interlayers of Gypsum and Anhydrite (Figure 2). The oil-bearing complexes of the Paleogene of the Lyalmikar, Koshtar and Mirshadi fields are represented by the Bukhara-Akzhar tier (Figure 3, line B-B). In addition to the Bukhara-Akzhar, Uchkyzyl Square is also the Alai layer. Here, the thickness of the Alai layer is $50 \mathrm{~m}$, and the Bukhara-Akzhar layer is $280 \mathrm{~m}$. 
The thickness of the Bukhara-Akzhar layer in Kokayti Square is $393 \mathrm{~m}$, in Lyalmikar-390 m, in Koshtar-180 m. In the Uchkyzyl and Kokayti deposits, limestone and dolomite with gypsum and anhydrite interlayers are Water-bearing rocks. In the Lyalmikar, Koshtar, Mirshadi deposits, in addition to the noted rocks, there are marls and interlayers of sandstone. This indicates that the Bukhara and Akzharlonglines are sulphate-containing (gypsum and anhydrite). It should be noted that such sulphate-containing strata are spread over almost the entire area of the Surkhandarya Basin under consideration. However, not all conditions arise for the formation of hydrogen sulfide Water.

Other not less important factor having an impact on conditions of formation of hydrosulphuric water is the geostructural factor. The analysis of the available data with allocation of zones of explosive violations, explosive and folded dislocations, the general structural plan and distribution of hydrosulphuric water was made

Based on the analysis of the structural map, regional transverse geological section, as well as hydrogeological testing in the drilled wells, geostructural and hydrodynamic factors were analyzed. Of the structural features, the depth and tectonic disturbance of the sedimentary rock complexes are important.

As it was noted above, paleogen and cretaceous sedimentary complexes are bared in a peripheral part of the hollow. In addition, there are outcrops on the surface of the Bukhara Paleogene complexes in the arched parts of the Dosmanaga and Aktaudeposits. The depth of their occurrence gradually increases in the direction from the eastern side of the depression to the axial zone of the depression, and then again there is a rise from the axial zone to the west. On the Amudarya area, the absolute elevations of the roof of the Bukhara layers reach values from -800 to $-1000 \mathrm{~m}$. The oil and gas fields of Dzhairankhan, Aktau, Korsagly and Amudarya are located closer to the eastern peripheral part of the depression. Within the limits of the Dzhairankhan deposit, the Bukhara layer lies in the interval of depths from -1700 to $-2500 \mathrm{~m}$. Within the deposits of Kokayty, Lyalmikar and Koshtar, the oil-bearing complex is noted at depths from -400 to $-2000 \mathrm{~m}$.

The Uchkyzyl, Haudag, Jalair and Mirshad fields are located closer to the central part of the Basin under study. Here, the Bukhara layer lies in the depth interval from -1000 to $-2000 \mathrm{~m}$. At great depths (below $-2000 \mathrm{~m}$ ), the Bukhara layer is noted in the anticlinal structures Angor, Ashurkhan, Kizirmazar, Dzharkurgan, Akjar, Kyzyltepa, Batash, Khitayan and Pakhtabad in the central part of the artesian Basin. Almost all oil and gas fields, where there are favorable conditions for the formation of hydrogen sulfide Water, there are longitudinal tectonic faults. On all noted squares on these upthrust gaps the western blocks are raised and it is pulled over east block. The amplitude of uplifts reaches about 300 $\mathrm{m}$ on average. Oil wells are located mainly in the western elevated blocks.

The analysis of materials shows the existence of close connection between geostructural and hydrodynamic conditions. 


\section{Results and Discussion}

Based on the analysis of the lithofacial features of the section in comparison with oil and gas bearing and halogen formations, we have compiled a map of the main areas of distribution of hydrogen sulfide water within the Surkhandarya artesian Basin (Figure 5). The map shows areas favoring the formation of hydrogen sulphide Water in the distribution of evaporitic sediments of Paleogenewater-bearing rocks, combined with oil and gas deposits. In essence, this is a forecast of promising areas for hydrogen sulfide water.

Hydrogen sulfide water are promising in the areas of discovered deposits in the southern part-Uchkyzyl, Jairankhan, Amudarya, Korsagly, Aktau, Kokayty, Khudag, Jalair; in the eastern part-Lyalmikar, Koshtar, Mirshadi, as well as within the anticlinal structures Shorbulak and Kurgancha. The map shows the contour of the distribution of sulphate-containing strata over Paleogene sediments (see Figure 5) as a zone for the joint development of halogen rocks and oil and gas complexes. This map can be called a paragenesis map of hydrogen sulphide water with evaporites and oil and gas complexes.

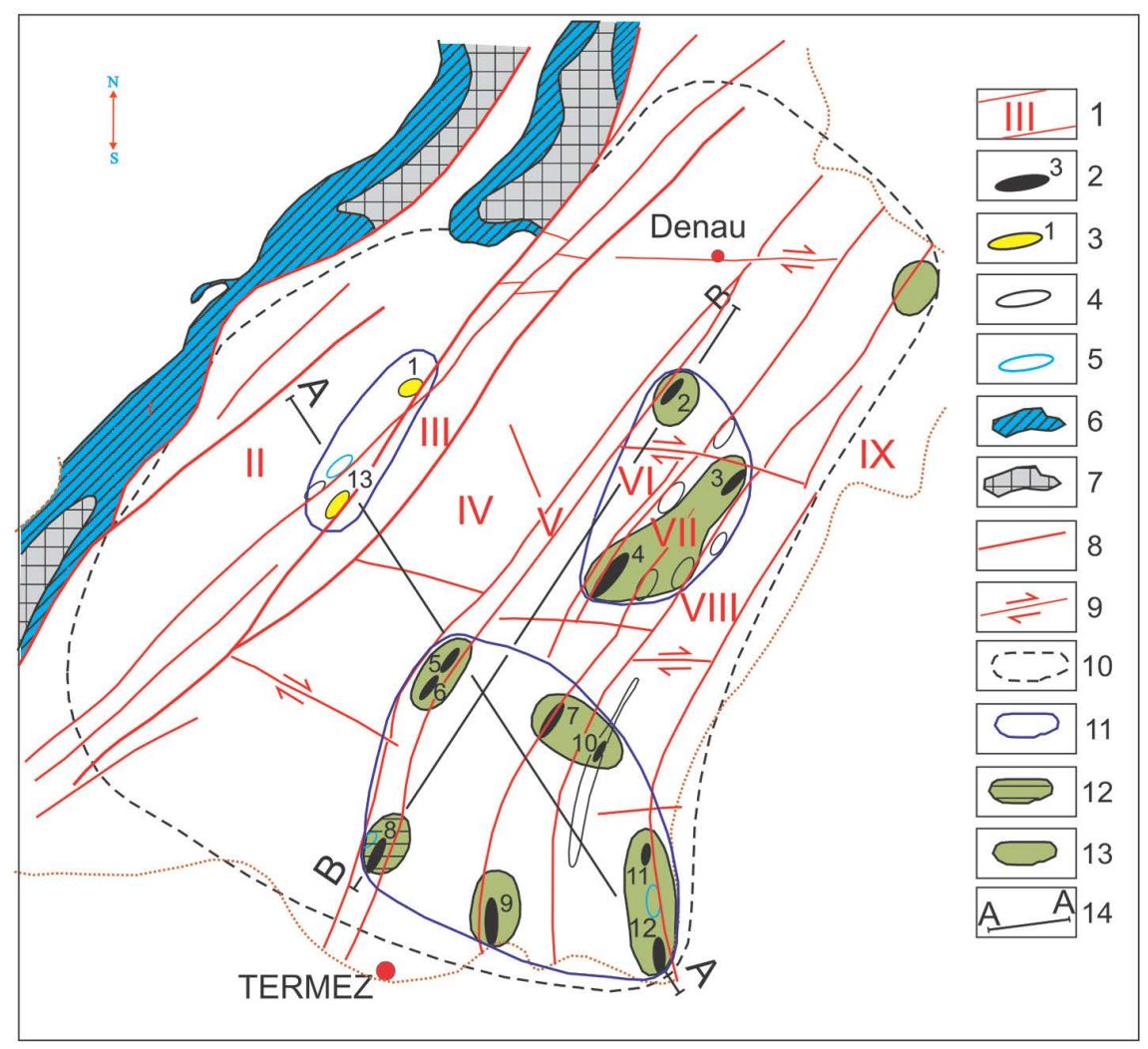

Figure 5. Schematic map of the distribution of paragenesis zones of hydrogen sulfide water with evaporites and petroleum complexes. Legend: 1 -tectonic block and its number; field: 2-oil, 3-gas; areas: 4-promising, 5-identified; 6-outcrops of the Jurassic; 7-exits to the surface of the Paleozoic formations; 8-faults; 9-shifts and boundaries of latitudinal steps (blocks) along ancient sediments; 10-the limits of the spread of evaporite sediments; 11-boundaries of developed and existing oil and gas fields; hydrogen sulphidewater development areas: 12-established, 13-promising; 14-profile lines. 
In this zone, the oxidative reaction is carried out due to the leaching of sulphate-containing strata. A reduction reaction with hydrogen and the participation of sulfate-reducing bacteria occurs in the oil-bearing layer. In the absence of one of the necessary conditions (sulfates or petroleum organics), hydrogen sulfide water of high concentration are not formed.

When studying the influence of the geostructural factor, it was taken into account that in the process of infiltration water exchange for a long geological time, dissolved free oxygen penetrates to considerable depths (up to $2 \mathrm{~km}$ or more) and spreads across permeable formations to a distance of tens of kilometers [9]. In oil fields, where hydrogen sulfide water are formed, the productive horizon lies close to the surface of the earth, which provides it with oxygen and enhances the process of sulfate reduction due to the infiltration of infiltration water through tectonic faults. The roof of the productive (Bukhara) layer of the Paleogene lies at a depth of $-200 \mathrm{~m}$ (Uchkyzyl) to $-1700 \mathrm{~m}$ (Jairankhan). It is at these depths that hydrogen sulfide water is formed.

The study area can be divided into three types according to the depth of the productive horizon-shallow, medium depth and deep. The eastern part of the studied region is attributed to the shallow (up to $2 \mathrm{~km}$ ), the western part of the territory to the middle (with depth more than $2 \mathrm{~km}$ ) and the central part of the region to the deep (considerable depths).

Hydrodynamic conditions are seriously affected by disturbed oil fields by discontinuous disturbances. The analysis of structural maps showed that almost all deposits cut through longitudinal tectonic disturbances. For these faults, infiltration water seep into the oil-bearing horizons and create conditions for the formation of hydrogen sulfide water.

Analysis of the hydrodynamic situation with the compilation of a geological section (Figure 3) taking into account the structural features (inclined occurrence of the Mesozoic-Cenozoic complex from the east to the central part of the artesian Basin, as well as the presence of hydrodynamic barriers due to tectonic disturbances) allows us to distinguish the eastern part of the territory as the most favorable for hydrogen sulfide water formations (Figure 6).

In the zone of hydraulic pressure Water between the eastern periphery and the central part, the Paleozoic and Cretaceous-Jurassic formation water is discharged upwards. The deceleration of the water exchange process in the arched part of the western wing of oil fields has been established. As a result, microbes (organic substances) are excited in the oil layer, i.e. sulfate-reducing processes occur and, as a result, Paleogene hydrogen sulfide water is formed.

In the analysis of hydrogeological data on the chemical composition of underground waters of the Paleogene availability of hydrosulphuric water on oil fields of Aktau and Dosmanaga is not confirmed. However, these areas are characterized by favorable conditions for their formation. However, these areas are characterized by favorable conditions for their formation. Therefore, we can assume the presence of hydrogen sulphide water in the area of Aktau and Dosmanaga oil fields. According to the degree of activity of water-pumping systems, the 


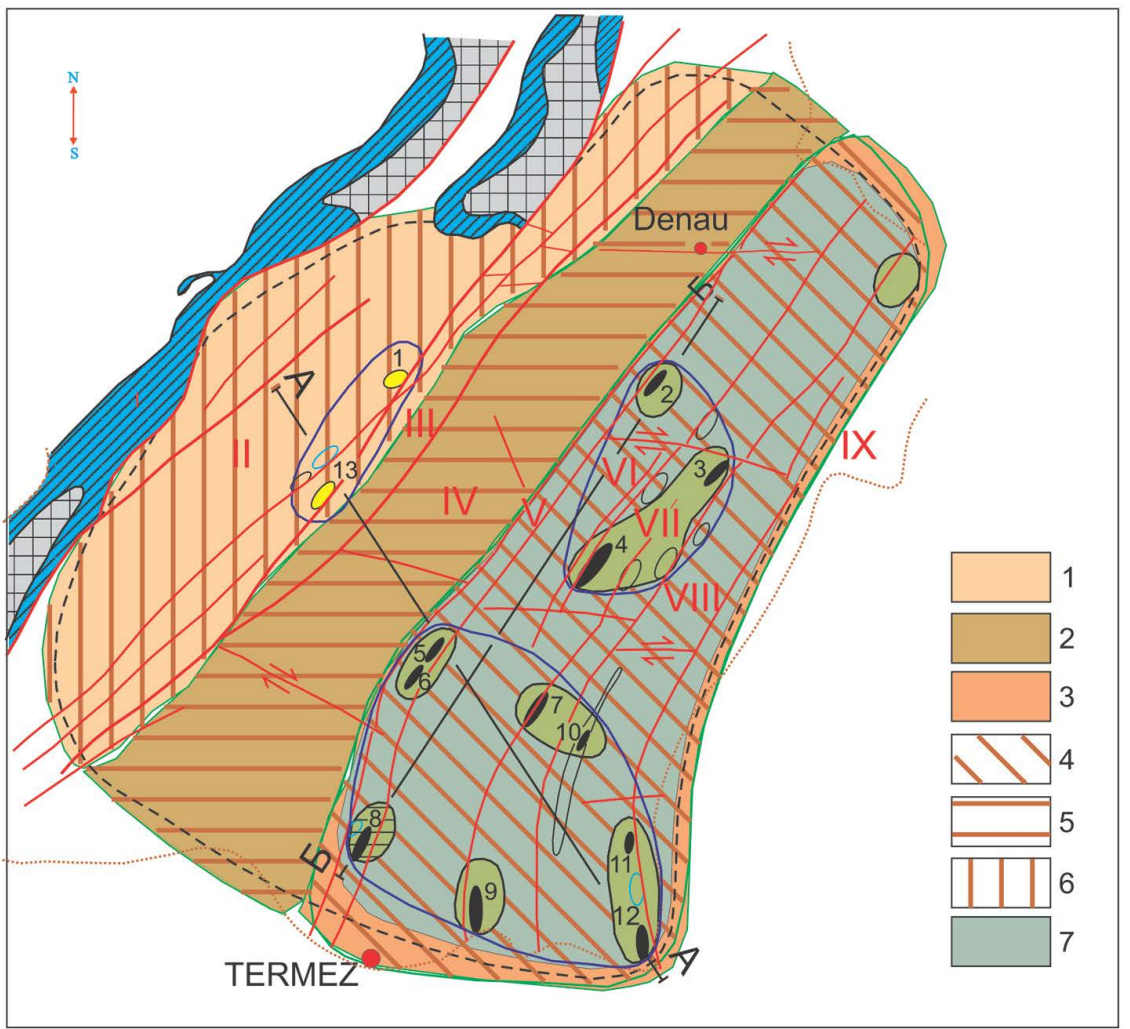

Figure 6. Forecast map-scheme of promising areas of hydrogen sulfide water of the Surkhandarya Basin on the complex of lithofacies, structural-geological and hydrodynamic features. Legend: 1 - 3-water pressure systems: 1-active, 2-weak, 3-insignificant. The areas of different depths of the oil-bearing horizon: 4-shallow (up to $2 \mathrm{~km}$ ), 5-average depth (more than $2 \mathrm{~km}$ ), 6-deep. 7-promising area for hydrogen sulfide Water (see the rest in Figure).

territory is divided into the eastern part (strong activity), western (weak activity) and central part (insignificant activity).

Places of a congestion of hydrogen sulfide are noted by negative Eh values that accords with the principles of formation of hydrosulphuric water in the environment with rather low extent of leaching, i.e. $\mathrm{Cl} / \mathrm{Br}=200-300$ at the high content of bromine and iodine in the oil-bearing horizon of the Paleogene. At the insignificant maintenance of ions of sulfate in very high content of hydrogen sulfide in reservoir water can be formed that at the high content of ions of sulfate is practically not expected.

On the basis of the analysis of a hydrogeochemical situation the following data are specified. At bedding of the productive horizon at a depth about $1000 \mathrm{~m}$ in water concentration of hydrogen sulfide reaches values of $250-500 \mathrm{mg} / \mathrm{l}$. At increase in depth up to $1500 \mathrm{~m}$ concentration makes $50-100 \mathrm{mg} / \mathrm{l}$. At depths more than $1500 \mathrm{~m}$ reduction of concentration of hydrogen sulfide is observed. It is possibly caused by penetration of oxygen from the Earth's surface.

At increase in a mineralization of reservoir water (more than $150 \mathrm{~g} / \mathrm{l}$ ) concentration of hydrogen sulfide decreases. Places of a congestion of hydrogen sulfide 
are noted by negative Eh values that accords with the principles of formation of hydrosulphuric water. Hydrosulphuric water is formed due to process of leaching and for this purpose the insignificant maintenance of ions of sulfate is necessary. Thus, the dissolved hydrosulphuric gas $\left(\mathrm{H}_{2} \mathrm{~S}\right)$ is formed in reservoir water of the oil horizon at the expense of a certain favorable hydrogeochemical situation.

Thus, the received results and their comparison to other known materials reasonable allocation of prospective areas of hydrosulphuric underground waters in the Surkhandarya artesian basin on the basis of the specified favorable environment allows. Figure 6 shows a synthesized map of forecasting prospective zones with favorable conditions for the formation of hydrogen sulfide water along a complex of lithofacies, structural, hydrodynamic factors. According to this Map, favorable specific natural conditions exist mainly in the eastern part of the Surkhandarya Basin. She highlighted as a promising area.

\section{Conclusions}

The study of the possible conditions for the formation of hydrogen sulphide water within the Surkhandarya basin of Uzbekistan allowed us to draw the following main conclusions.

As the main condition for the formation of hydrogen sulfide water, the presence of such specific natural features as oil and sulphate-containing strata is necessary. In sections of almost all hydrocarbon deposits of the Surkhandarya region, there are sulfate-bearing strata.

Favorable structural conditions have been established: a shallow depth (up to $2 \mathrm{~km}$ ) and the presence of an asymmetric anticlinal structure with intersecting tectonic disturbances, along which infiltration water penetrates to the productive horizon. A favorable condition is the active hydrodynamic setting (the flow of groundwater along inclined horizons with the creation of hydro-pressure in tectonically screened layers).

Favorable hydrogeochemical conditions with $\mathrm{pH}$ range from 6 to 8, reservoir Water with high mineralization (from 10 to $50 \mathrm{~g} / \mathrm{l}$ ); a slight presence of sulfate ions, the leaching process from 200 to 300 units, the temperature of the reservoir water of the productive horizon from $28^{\circ} \mathrm{C}$ to $70^{\circ} \mathrm{C}$.

It should be noted that the unloading of thermal water along tectonic fractures leads to the leaching of sulfate-containing strata and to an oxidative reaction with the formation of hydrogen sulfide water. The presence of evaporite (calcareous and gypsum) Rocks and oil-bearing strata favors a reducing reaction with hydrogen with the participation of sulfate-reducing bacteria.

Within the Surkhan-Darya artesian basin, favorable specific natural conditions were established only in the eastern part, where shallow deposits of oil-bearing strata and the corresponding hydrodynamic regime of Groundwater are observed.

The method considered in the present work can be used for predictive studies of the prospects of other areas for hydrogen sulfide water. 


\section{Conflicts of Interest}

The authors declare no conflicts of interest regarding the publication of this paper.

\section{References}

[1] Bernard, W.P., Henri, G.D., Hillebrands, J.-L., van Goor, H. and Bos, E.M. (2016) The Role of Hydrogen Sulfide in Aging and Age-Related Pathologies. Aging, 8, 2264-2289. https://doi.org/10.18632/aging.101026

[2] Miller, D.L. and Roth, M.B. (2007) Hydrogen Sulfide Increases Thermotolerance and Lifespan in Caenorhabditis elegans. Proceedings of the National Academy of Sciences of the United States of America, 104, 20618-20622.

https://doi.org/10.1073/pnas.0710191104

[3] Qabazard, B., Li, L., Gruber, J., Peh, M.T., Ng, L.F., Kumar, S.D., Rose, P., Tan, C.H., Dymock, B.W., Wei, F., Swain, S.C., Halliwell, B., Stürzenbaum, S.R. and Moore, P.K. (2014) Hydrogen Sulfide Is an Endogenous Regulator of Aging in Caenorhabditis elegans. Antioxidants \& Redox Signaling, 20, 2621-2630.

https://www.ncbi.nlm.nih.gov/pubmed/24093496

https://doi.org/10.1089/ars.2013.5448

[4] Ivanov, V.V. (1977) Sulfide Water of the USSR. "Profizdat”, Moskou, 257 p.

[5] Anisimov, L.A., Kireeva, T.A., Bankin, K.I., Krasnyashchikh, O.S. and Lyamina, L.A. (2017) Formation of Hydrochemical Indicators for Productive Layers of Oil Fields of the Surgut Arch. Bulletin of the Moscow University, Series 4, Geology 2, 57-65.

[6] Marriott, R.A., Pirzadeh, P., Marrugo H., J.J. and Raval, S. (2015) Hydrogen Sulfide formation in Oil and Gas. Canadian Journal of Chemistry, 1-32. https://tspace.library.utoronto.ca/bitstream/1807/71464/1/cjc-2015-0425.pdf

[7] Amitabha, M., Al-Haddad, A., Al-Otaibi, M. and Al-Senafy, M. (2007) Kuwait Occurrence of Hydrogen Sulfide. Environmental Geology, 52, 1151-1161.

[8] Simonton, D. and King, S. (2013) Hydrogen Sulfide Formation and Potential Health Consequences in Coal Mining Regions. Water Quality Exposure and Health, 5, 85-92. https://doi.org/10.1007/s12403-013-0090-6

[9] Zhuraev, M.R. (2016) Refinement of Geostructural and Hydrodynamic Factors during the Formation of Hydrogen Sulphide Water in the Surkhandarya Megasyncline. Exploration and Protection of Mineral Resources, 4, 37-43.

[10] Zhuraev, M.R, Abdullaev, Sh.H., Nagevich, P.P. and Tursunmetov, R.A. (2015) Clarification of the Conditions for the Formation of Hydrogen Sulfide Water of the Fergana Basin according to the Results of Geophysical Studies. Perm University Herald. Geology, 1, 28-37.

[11] Zhurayev, M.R., Bakiyev, S.A. and Tursunmetov, R.A. (2015) The Characteristic Hydrogeochemical Situation the Hydrogen Sulfide Contain of Oil-and-Gas Fields of the Southern Board of the Fergana Hollow. The New Ideas in Sciences about Earth: T. XII, The International Scientific and Practical Conference, Russian State Prospecting University, Moscow, 8-10 April 2015, 328-329.

[12] Pavlova, A.V., Krylova, O.V. and Vasnetsova, O.A. (2018) Classification of Mineral Waters. Фармация, 67, 8-13. https://elibrary.ru/item.asp?id=32498079 